\title{
NETWORK AND SOCIAL SUPPORT IN CHILDREN WITH CHRONIC DISEASES: UNDERSTANDING THE CHILD'S PERCEPTION ${ }^{1}$
}

\author{
Maria Elizabete de Amorim Silva², Flávia Moura de Moura³, Tarciane Marinho Albuquerque ${ }^{4}$, Altamira Pereira \\ da Silva Reichert ${ }^{5}$, Neusa Collet ${ }^{6}$
}

\footnotetext{
${ }^{1}$ Article connected to the research project - Rede, apoio social e cuidado em saúde na condição crônica na infância, financed by CNPq, Universal Edital 475841/2010-7.

${ }^{2}$ Doctoral student, Programa de Pós-Graduação em Enfermagem, Universidade Federal da Paraíba (UFPB). João Pessoa, Paraíba, Brasil. E-mail: elizabeteamorim.enf@gmail.com

${ }^{3}$ Ph.D. in Nursing. Professor, Unidade Acadêmica de Psicologia, Universidade Federal de Campina Grande. João Pessoa, Paraíba, Brasil. E-mail: flavia.m.moura@uol.com.br

${ }^{4}$ Doctoral student, Programa de Pós-Graduação em Enfermagem,UFPB. João Pessoa, Paraíba, Brasil. E-mail: tarci_marinho@hotmail.com

${ }^{5}$ Ph.D. in Child and Adolescent Health. Professor, Departamento de Enfermagem em Saúde Coletiva (DESC) and Programa de PósGraduação em Enfermagem, UFPB. João Pessoa, Paraíba, Brasil. E-mail: altareichert@gmail.com

${ }^{6}$ Ph.D. in Nursing. Professor, Programa de Pós-Graduação em Enfermagem and Departamento DESC/UFPB. João Pessoa, Paraíba, Brasil. E-mail: neucollet@gmail.com
}

\section{ABSTRACT}

Objective: to identify the network and social support in the perception of children with chronic disease.

Method: qualitative research conducted with eight children with chronic disease, between November 2012 and June 2013 in a public hospital in Paraiba, Brazil. An adaptation of the drawing-story process with theme was used. The data were interpreted by thematic analysis.

Results: in some moments of life, the child receives different types of support that are offered by strengthened links that make up their social network. But this network has not always proven to be strengthened and able to provide the necessary support to adequately cope with the disease.

Conclusion: health professionals need to direct their focus on the child, listening to them and their singularities and helping to identify links in their social network which can provide them with the support they need to cope with chronic illness.

DESCRIPTORS: Pediatric nursing. Social networking. Social support. Chronic disease. Child.

\section{REDE E APOIO SOCIAL NA DOENÇA CRÔNICA INFANTIL: COMPREENDENDO A PERCEPÇÃO DA CRIANÇA}

\section{RESUMO}

Objetivo: identificar a rede e o apoio social na percepção da criança com doença crônica.

Método: pesquisa qualitativa, realizada entre novembro de 2012 e junho de 2013, em um hospital público da Paraíba (Brasil), com oito crianças com diagnóstico de doença crônica. Utilizou-se uma adaptação do procedimento de desenho-estória com tema. Os dados foram interpretados por meio da análise temática.

Resultados: em alguns momentos da vida, a criança recebe diferentes tipos de apoio, que são oferecidos por vínculos fortalecidos que compõem sua rede social. Entretanto, nem sempre, essa rede se mostrou fortalecida e capaz de oferecer o apoio necessário ao enfrentamento adequado da doença.

Conclusão: os profissionais da saúde precisam direcionar seu olhar para a criança, ouvindo-a em suas singularidades e ajudando a identificar elos em sua rede social, que possam lhe fornecer o apoio de que precisam para enfrentar a doença crônica..

DESCRITORES: Enfermagem pediátrica. Rede social. Apoio social. Doença crônica. Criança. 


\section{RED DE APOYO SOCIAL EN LA ENFERMEDAD CRÓNICA INFANTIL: COMPRENDIENDO LA PERCEPCIÓN DEL NIÑO}

\section{RESUMEN}

Objetivo: identificar la red y el apoyo en la percepción del niño con enfermedad crónica.

Método: investigación cualitativa, realizada entre noviembre de 2012 y junio de 2013, en un hospital público de Paraíba, Brazil, con ocho niños con diagnóstico de enfermedad crónica. Se utilizó una adaptación del procedimiento del diseño-historia con tema. Los datos fueron interpretados por medio de análisis temático.

Resultados: en algunos momentos de la vida, el niño recibe diferentes tipos de apoyo, que son ofrecidos por vínculos fortalecidos que componen su red social. Sin embargo, ni siempre esta red se mostró fortalecida y capaz de ofrecer el apoyo necesario al enfrentamiento adecuado de la enfermedad.

Conclusión: los profesionales de salud necesitan direccionar su mirada para los niños, oyéndolos en sus singularidades y ayudando a identificar eslabones en su red social que puedan proporcionar el apoyo que necesitan para enfrentar la enfermedad crónica.

DESCRIPTORES: Enfermería pediátrica. Red social. Apoyo social. Enfermedad crónica. Niño.

\section{INTRODUCTION}

Advances in science have enabled early diagnosis of chronic diseases in childhood. ${ }^{1}$ The United States is faced with a rate of $19.3 \%$ of children with special health care needs, ${ }^{2}$ among which include those with diagnosis of a chronic disease, which accounts for $42 \%$ of health care costs for the child population. ${ }^{3}$ In Brazil, research reveals that $9.1 \%$ of children aged zero to five years present with chronic diseases, as well as $9.7 \%$ of schoolchildren between six and thirteen and $11 \%$ of adolescents aged fourteen to nineteen years of the general total population. ${ }^{4}$

Children with chronic diseases may present physical and neurodevelopment complications ${ }^{1}$ giving reason to why they need to learn to live with a new reality for the proper management of the disease. In general, this implies limitations of activities, following a specific diet, being submitted to painful procedures, body changes and repeat hospitalizations. ${ }^{5}$

Studies of children and adolescents living with different chronic diseases show the importance of social support in order to face the disease..$^{5-6}$ The stories they tell and how they understand their life contexts are challenged by memories of past events and present and future representations. ${ }^{7} \mathrm{~A}$ strategy for effective coping with the chronic childhood condition is the support offered by members of the social network, which join forces to support, in various ways, the child and his family, minimizing their necessities. ${ }^{5,8}$ The social network is established more broadly through the institutions that are connected to those who experience the disease in their daily life. ${ }^{9}$ Social support is one of several ways for network members to give assistance, material or otherwise, for the child and their family. ${ }^{10}$

Network and social support are key to coping with chronic illness. Seeing them from the point of view of the person who requires care, in this case the child, means to mobilize people and resources to meet their unique needs. In this way, it can provide support for health professionals to participate in the network building process to promote effective support for the maintenance of the social life of the child, despite the vicissitudes of the chronic disease. Moreover, it is important to build elements of care which help supporters of children with chronic diseases in order to strengthen their care potential and positively affect the experience of the chronic condition. In this context, it is questioned: who makes up the network and provides social support for children with chronic disease in your perception? In order to answer this question, this study aims to identify the network and social support in the perception of the children with chronic disease.

\section{METHOD}

A qualitative survey, conducted between November 2012 and June 2013, in a public hospital in the city of João Pessoa, Paraíba, Brazil, with eight children with chronic disease. Two were hospitalized and six were outpatients. They were selected based on the following inclusion criteria: diagnosis of chronic disease; be a child of school age, between six and twelve years; receive medical care at the clinic; and be present at the time of data collection in the hospital / the pediatric unit of the hospital. As exclusion criterion was used: have difficulty communicating verbally and interacting with the researcher.

In order to produce the empirical material an adaptation of drawing stories with themes was used 
to understand the subjectivity of achild. ${ }^{11}$ In this procedure, the child is asked to make a series of drawings, then tell a story associated to it, to give explanations ("investigation" phase) and, finally, to give it a title. ${ }^{12}$

In order for it to be a technique of adaptation, the series of five drawings was not carried out, as is established, nor were they analyzed. The empirical analysis was made up of the stories told by children from their drawings and the reports were obtained in the investigation stage. The drawing was the device used to approach the children and also used to start the research object content.

The children drew two drawings, one free style and the other based on a theme, in a single session, which duration varied from child to child. The free style drawing was carried out after making contact with the researcher, so that the child knew the technique. When they were finished, the children were asked to tell the story about the material. Then the process was followed up with the investigation stage, which involved asking the children some questions in order to clarify the drawing and to stimulate new associations on the material. Finally, the child was asked to give a title to their story. This process was done with each drawing.

Then the child was asked to represent the subject of this investigation by using the drawing, with this guiding question: "I would like you to make a drawing of child who has a disease and is in treatment." From this initial question, the research was directed towards the understanding of the network and social support of children who face chronic disease and treatment. A pilot test was conducted to validate the technique. ${ }^{13}$ The stories and explanations presented by children were recorded in electronic media and later fully transcribed for analysis.

For the interpretation of the data, thematic analysiswasused. ${ }^{13}$ After transcribing the interviews, the first organization of reports was performed, initializing classification. The horizontal map material was drawn. Subsequently, the research proceeded to the exhaustive and repeated reading of the texts, making an interrogative relationship to seize the relevant structures. The procedure allowed elaborate classification by cross-reading. From the relevant structures, the downsizing of the rating was processed, regrouping the most relevant topics.

The ethical principles recommended by Resolution No. 466/12 of the National Health
Council were respected. The study was approved by the Institutional Ethics Committee, CAAE 50019715.6.000.5183. The children signed the Informed Consent Form for minors, and the adults responsible for them signed the Informed Consent Form. To ensure the anonymity of the participants, fictitious names of characters from children storybooks were used, chosen randomly by the researcher, such as: Peter Pan, Cinderella, Snow White, Chico Bento, Rapunzel, Belle, Jasmine and Aladdin.

\section{RESULTS AND DISCUSSION}

The study participants included were five female and three male children, with ages ranging from six to 11 yearsof age, with the following medical diagnosis: Diabetes Mellitus type 1 (4); hyperthyroidism (1); nephrotic syndrome (1); chronic asthma (1) and cirrhosis with subsequent liver transplantation, and histiocytosis $\mathrm{X}$, with consequent development of Diabetes Insipidus (1). The shortest time of diagnosis was two months, and the longest was ten years. Only one of the children resides in the city of João Pessoa, Paraíba, the others live in the state of Paraíba.

From empirical material analysis, different themes were extracted, which were grouped into two categories: 'The network and social support of children with chronic disease' and 'Weakened social network due to required support being reduced'.

\section{The network and social support of children with chronic disease}

The child who experiences chronic disease needs to be heard, so that their real care demands are highlighted. Through drawing and telling the story, she expressed her innermost feelings. During the narrative, it is clear, that she confused the subject in the reports between the character she created and herself the child.

The experience of adversity is less painful when the child can have an effective social network that is able to offer support at all stages of chronic disease. Children describe family support in the daily care required by the disease. For them, the actions for the proper management and control of the disease are greatly relevant.

The mother and father help to give the insulin and measure the glucose [...]. I feel joy. [...] Happy to have 
someone by my side, helping me (Peter Pan - 11 years); her grandmother [child's drawing] [...] gives medicine to her to get well and go to school (Bela - 6 years).

Family support is present in the child's daily life and can be demonstrated in the care and attention in relation to tratament. ${ }^{14}$ The knowledge acquired over time provides the family with the empowerment necessary to carry out the daily care, which will be learned and, in the future, will be performed by the child. However, for families and children to obtain this knowledge, health professionals should be available to talk, listen and support, exchanging knowledge and giving information.

Knowledge about chronic disease and treatment is essential for the child to receive care at home. Snow White points out that many members of her social network give her support. However, the only person who has knowledge about the care related to treatment is her mother, who supports her in a unique and comprehensive manner. The other members of the network need to communicate with this family member to know how to administer the treatment.

My mother often travels to a city that is really far from the [city of residence],so my father prepares my breakfast, does my test [blood glucose], gives my injection [insulin]. He calls my mother and asks how much it is [blood glucose], and asks how many units of insulin. [...] My grandmother, my aunt, [...] when my level [glucose] is low, they call my mother, ask what they should do, they give me honey, which is inside the bag of my tests. [...] I wish she [grandmother] knew [...] how to do my test [blood glucose] and give my injection [insulin]. [...] When I'm feeling bad, the director or the teacher calls my mother. [...] I would like them to also know how to do my test [blood glucose] and give my insulin. [...] It would be very important, so that when $I^{\prime} m$ in the playground and it goes low [blood glucose], she [teacher] knows how to do it. [...] it would help me to do well in school (Snow White - 8 years).

The child's story demonstrates its desire that other network members also know how to take care of her illness because she could continue her life in a qualified way, no absences, especially those related to school.

Parents of the child are indispensable caregivers, however, mothers are identified as the main source of social support. Few studies demonstrate the effective involvement of the father in the care directed tochildren. ${ }^{15}$ Through health education, professionals in this area must involve the family in the educational process and the care given to children with chronic illness, offering the necessary assistance so that their skills are developed, and so that they can have independence and autonomy and are able to accept and manage the children's daily health condition. Thus, it will be easier to prevent hospitalizations. ${ }^{16}$

Each meeting between health professionals, children with chronic illness and their families can be transformed into a therapeutic point of care, promoting the role of those involved in this process. Therefore, effective health education practices must take place, overpassing vertical knowledge, which is guided by a unilateral provision of explanations and giving rise to spaces for reflection and the exchange of experiences and knowledge, the dialogical relationship with qualified listening, the appreciation of the knowledge of the child and family. In addition, we need to enable meetings between those who have similar experiences, so there is exchange and construction of knowledge between them.

Peter Pan states that he receives informational support necessary for care therapy from some health professionals. For him, the support received is a guarantee of survival.

I get [support] in the hospital. The doctor and the nurse give me the right things for me to control my diabetes. [...] If the arm is hard, it's because too much insulin was injected in one part. [...] they help [doctor and nurse] teaching how to give insulin. [...] I think it's cool, $[. .$.$] because if it were not for them, or some medical$ centers, we would die of diabetes (Peter Pan - 11 years).

Children who experience chronic illness can understand their disease and make decisions regarding their care process. The health team needs to have that understanding and adopt strategies that enable the active participation of children in the control disease. ${ }^{7}$

The daily care of the child, carried out by family members, as well as the concern and willingness to accompany them to health services when they need care, are all mentioned as offering social support, by effective supportive bonds, who are available to help and to be with the child to face the chronic condition with less difficulty.

Her mother [child's drawing] gives her a bath. [...] Makes food for her, takes her to school. [...] Takes her 
to the doctor, [...] wherever she is, her mother will help (Cinderella - 7 years); my cousin, [...] she used to take me to the hospital. When I was away who took me was my mother, but for other [city hospitals where she lives], she [the cousin] used to take me (Rapunzel - 11 years).

The effective participation of the family in the daily care provided to a child with chronic illness is essential. The proactive approach is a way to facilitate coping with chronic disease in childhood, because it promotes to meet the demands that arise. The perception of support received by the child for further treatment covers different dimensions. The action of providing conditions for the trip to the state capital for medical consultations, which take place routinely in chronic condition, is also identified as a social support.

He [stepfather] got the car from his brother, we came [hospital] me, him and my mother (Rapunzel 11 years); in the city, they give the transport [to go to medical consultations]. [...] The bus, they bring all the sick people here [the state capital]. [...] I think it's cool saving people (Peter Pan - 11 years).

The financial impact brought by the disease, commonly affects, the aggravation of the situation experienced, and one of the difficulties in chronic condition is the increased costs related to transport for the treatament. ${ }^{17}$ Children realize this need and the support received for to minimize the problem. So it is important that there is always a source of social support to minimize the family expenses with treatment and to promote appropriate follow-up of treatment and continuity of care.

Support for the outpatient treatment is not limited to the offer of transport to medical consultation, but also extends to emotional support from extended family members, such as the grandmother, who, in an act of love and care, helps the child to wake up and gives him the strength to get up and face adversity, such as long and uncomfortable trips.

[grandmother] wakes me every time I come here [the state capital]. [...] She takes my hand, then I get up. [...] I'm quiet (Bela - 6 years); my uncle brought me [to consultations in the state capital] with my mother and my grandmother, my grandmother comes to me, she takes care of my things when I have a consultation with the doctor. [...] My grandmother is in the back [of the car] with me, making many plans, I lay in her lap and sleep. [...] Sometimes she sings (Snow White - 8 years).

When the family support is satisfactory, it generates courage and comfort, it allows well-being and improves quality of life. ${ }^{14}$ A conversation, a touch, a caress, a lap, are all displays of affection that benefits the lives of children, because they meet their natural care demands. Plans for the future must remain part of their lives, because they move and give energy to cope with the health problem that they will have to continue living with. This kind of support is essential for school children so that they feel encouraged in this process.

The emotional support of parents, especially the mother, comforts, satisfies and brings well-being and happiness to the child. When strength, comfort and tranquility are offered, hope is renewed, and she is strengthened to continue to live with the disease, successfully facing the imposed implications.

The mother gives strength, [...] she is close to him [child's drawing], talking to him, holding his hand, helping him to calm down. [...] Helps him feel better. [...] he is not scared and makes him feel less sad (Chico Bento - 11 years); his mother [child's drawing] was always by his side [...]. She told him the pain he was feeling would pass. [...] he was better, because it helped to pass what he was feeling. [...] I felt more cheerful. [...] He didn't think he was going to die anymore and thought his mother was an angel who was protecting him so that he would not die (Jasmine - 11 years); his mother [child's drawing] helps him [...] staying with him, looking after him, so that he wouldn't be alone [...]. It feels good, [...] feels safe (Aladdin -8 years).

In chronic illness, emotional support is even more important due to the stress caused by changes imposed by chronicity. In this context, the feeling of helplessness increases, and the need for support is evidenced. Emotional support is considered beneficial because it minimizes the suffering when faced with difficulties. Without it, it is much more difficult to face the disease, for this reason it is necessary to help people who are considered reliable and have a loving relationship with the child. ${ }^{18}$

The special attention and concern dispensed by members of the social network, such as school friends, the child's diet, are recognized as a way to offer support in fighting the disease.

They [school friends] care about me, they say: 'eat so that you won't be sick' [...]. They take care of me, say, 'do not eat too much salt, because of your illness' (Rapunzel - 11 years).

The solidarity attitude of a friend gives happiness to the child. She [school friend] is the only one 
who does not take candy to school so I do not see her eating it. [...] It is helping me [...]. I feel more cheerful, because she is my best friend (Jasmine - 11 years).

One study ${ }^{19}$ points out that the sweets that are brought to school, brought from home or purchased by friends, make it difficult to manage the disease in the school environment. The offer and sale of healthy food at school canteens nationwide, according to the recommendations by the ministerial decree of the Ministry of Health and Ministry of Education, n. 1,010 of 8 May 2006, ${ }^{20}$ instead of candies, sweets and soft drinks, can reduce the discomforts experienced by the child whose diet has restrictions, and encourages the adoption of healthier eating for all children.

The encouragement o family and significant others in the social network can strengthen health guidelines given to children with chronic disease and promote further accession, both recommendations of proper diet and medicinal therapy. ${ }^{21}$ This helps the child to follow a healthy and proper diet and improves their health and facilitates their experiences with the disease, providing them with quality of life.

Friends are also appointed as members of the social network of the child, offering emotional support as necessary for them to overcome the difficulties faced in the course of the disease. In times when the pain was present in the lives of children, friends appeared as a source of emotional support, with the ability to minimize the feelings at that moment. Consoling and play help them to forget the implications imposed by the disease, providing happiness and improving coping.

Friendship is already s lot [...]. When I suffer, when I play, [...] they [school friends] are always there to help. [...] They give faith, [...] playing, making us forget things [aspects related to the disease], saying that everything will be OK. [...] The friendship helps me to have more strength, [...] to face more [the disease] (Rapunzel - 11 years); his friends [child's drawing], [...] consoled him. [...] Because he always cried because he had no arm, their friends were there and helped him [...]. He was happy (Jasmine - 11 years).

There are some friends who experienced the same disease in their childhood. By experiencing what chronicity requires of them, sharing experiences, exchanging knowledge and feelings and putting themselves in the other's place as a way of understanding the situation.
I had a girl in my room, she had a disease near the kidneys [...]. To pass the time, in recess [between classes], It oldher about my life, what happened [the disease] and she talked about her. [...] I put myself in her place, [...] and she knew more or less how my life was (Rapunzel - 11 years).

The interaction between those who experience similar situations creates a supportive relationship, because, through awareness, sharing experiences and experiencing suffering, the interest in helping and caring for others grows. This process forms a strong networkofsolidarity. ${ }^{10}$ The emotional support of family, friends, people who share the same experience and/or health professionals greatly facilitates coping with the chronic condition. ${ }^{18}$

The child who experiences chronic disease often needs to miss classes. And to avoid losses in school performance, support of friends in relation to content and activities is needed. They are friends [from school] that when the person needs, they help when the person is missing something [from lass], they help, tell you what happened in the class (Rapunzel - 11 years).

To minimize the losses in the education of children who experience frequent hospitalizations, Resolution No 41/95, in the National Council for the Rights of Children and Adolescents, approves the rights of hospitalized children and adolescents, among which highlights the right to follow the school curriculum during their stay in hospital. ${ }^{22}$ Despite the current legislation, children do not always have this guaranteed right and depend on friends to accompany the school content for them.

Facing the disease would be more difficult if the children affected by this type of illness did not have the contribution of friends. ${ }^{19}$ They appear as full members of their social network and support at various times, to minimize the negative effects of the disease and make them forget, at least momentarily, its existence. Therefore, friends help children shift the focus from the disease.

The child needs to continue his daily life even with the existence of the disease. They need to be "a child", a social being that relates in different environments. Whether through school activities, either through play, she keeps exercising actions specific to childhood, such as playing. My mother is playing with me [...]. I am good, I feel cheerful (Chico Bento - 11 years); she [mother] plays with me. [...] We play the game of the old woman. [...] I feel better (Jasmine - 11 years). 
Health professionals also participate significantly in this type of support, imparting good feelings, smiles and joy to the children. They (the doctors) help me play. I play with them, I like them, it's good. [...] I pretend I am the lady in the carriage. [...] I'm happy, I feel good, smiling (Chico Bento - 11 years).

Play functions as a strategy which establishes trust and confidence between the child, the health service and its profissionals. ${ }^{23}$ The existence of a recreation room makes the hospital more pleasant for school children, because it gives them the opportunity to have fun, to relax and to forget the experience of illness and hospitalization. ${ }^{24}$ When playing, the child does not see only the negative aspects of the disease, but also forgets, temporarily, the adversities and experiences something that is his own, sharing time with other children with similar experiences.

Faith was considered as a source of support, because it consoles, strengthens and renews hope, allowing the child to believe in their healing and face the disease with more serenity. Faith helps her [child's drawing] to not have died until now, and also not to give up. [...] The strength to wake up every day and come to be poked, to do it again all you did the day before. [...] Helps her not to give up, always be stronger (Rapunzel - 11 years); God, [...] gives power to it [child's drawing] to continue living (Jasmine - 11 years).

Faith is an important social support found by the child, which helps the child to not feel alone and to believe in their recovery and in the future, with the possibility of a normal life, where there is no chronic condition. ${ }^{25}$ Support offered by members of the social network aims to minimize the demands presented in coping with the chronic disease. Qualified listening to children's experiences is a way for health professionals to understand the uniqueness of the social support in their lives. Attention, listening, exchange of knowledge and a watchful eye, sincerity and patience dispensed to children in order to favor the creation of a strengthened link between them and the health professionals and to contribute to the achievement of a sensitive, meaningful and effective care in living with chronic disease.

\section{Weakened social network due to required support being reduced}

Living with the disease is difficult to experience. Therefore in order for children to find strength to face adversity, they should receive support from members of their social network, who are important to them. However, links providing social support as needed in the living moment are not always available.

At the time of definition of the diagnosis, the child and his family are faced with a situation pervaded by experiences, routines and totally new medical terminologies. In seeking the health service, they require informational support to understand the situation. However, even with numerous demands for information and care, the only approach adopted by health professionals cited in the report is talking about the therapy.

This child [drawing] [...]. She had diabetes, and she did not know what it was, nor did the mother. They went to a medical facility, [...] they asked about help. [...] They just said [the health professionals] that insulin is the best method to control diabetes (Peter Pan - 11 years).

Health professionals responsible for informing the child and family of the diagnosis of a chronic disease, must demonstrate sensitivity. For this, they need to promote listening, dialogue, clarification of doubts and be receptive and understanding before expressing reactions. ${ }^{26}$

The bond between children and health professionals appears fragile. At times, it is unable to give what the child expects. The emotional support that could happen when performing painful procedures is insufficient. The child said that the attitude would be contrary to the adopted, with conversations and advice, respecting them in their singularity.

Doctors, people [Nursing professionals] [...] fight with him [child's drawing], they shout, because he is not quiet. [...] His mother, she complains to the doctors, not to shout at him [...]. He feels well and knows that no one will mistreat him [...] [doctors and nursing professionals]. They could help him, give advice to him, for him to leave [conducting the proceedings], because it is necessary and he will improve. [...] Speaking calmly, respecting him (Aladdin -8 years).

Children need unique and humanized professional care, which cannot be fragmented, technical or lack dialogue, however it must consider extended care. Reflecting on the care of hospitalized children in a comprehensive perspective, professionals must not limit themselves to drug interventions or rehabilitation techniques. ${ }^{27}$ Children clamor for their demands to be listened to in a qualified manner, listening to their demands, they clamor for the at- 
tention to what they think should be contemplated in their therapeutic project.

For health care to be comprehensive and effective, professionals must be a significant source of social support for children with chronic diseases. In this perspective, it is necessary to overcome the fragmentary care and bring the focus of action to their psychosocial needs.

The schoolchild expects to have the support of their school friends to face the impositions of the disease, such as diagnostic tests, painful procedures and dietary restrictions. However, sometimes they are faced with situations of bullying, social exclusion and isolation. These attitudes of her school friends make her suffer, and this further increases the difficulties that the disease imposes.

They [school friends] begin to mock and make fun, they start telling everyone that the person has made a lot of examinations, these things, and I don't like it, because I never shared my things with anyone. [...] They do not know what we suffer [...]. They do not know what is going on in our lives (Rapunzel - 11 years); I think it's bad when I see my friends [from school] eating sweets and calling me diabetic. [...] I felt upset because I couldn't eat sweets and they could, and they showed me they could. [...] If they would stop calling me diabetic. [...] I would feel better (Jasmine - 11 years).

The disease, frequent hospitalizations and impaired self-image hamper children's relationships in their social context and, in a special way, in relations with fellow students and education professionals. School should be a major source of support for them, however, this constituent of the social network does not strengthen the bond between them, their peers and teachers, showing to be unprepared to meet the real demands of children. ${ }^{28}$ It is believed that educational interventions about chronic illnesses in schools could transform this reality, because one of its determinants is disinformation.

Children would like that their friends receive information about their illness. ${ }^{19}$ The context demonstrates and reinforces that it is necessary to create health education programs for teachers and classmates of children and adolescents with chronic disease, with the presence of health professionals in schools, ${ }^{29}$ promoting educational interventions for information, to reduce prejudice and maintain an effective social life.

Regardless of location - at home, at school, in the hospital - a child with chronic illness must al- ways receive support from members of their social network, so they can strengthen and receive the encouragement necessary to successfully face the implications of the disease.

\section{CONCLUSION}

Throughout their history with chronic illness, the child receives different types of social support, and health care to maintain their well-being, toys and games that help to remove the focus of the disease and make room for the world of play and emotional, instrumental and informational support, in order to strengthen them in the daily life experience with chronic illness.

This support is provided by strengthened bonds that make up their social network, generally made up of the family, both nuclear family and extended family and healthcare professionals and friends, especially classmates. In the perception of some children, faith is also a significant source of strength and encouragement to live with the disease. However, this network has not always been strengthened and able to provide the necessary and satisfactory support for coping with the disease, considering that some potential supporters, as some health professionals and school friends, were not willing to support when the child needed it. This brought suffering in situations where the child expected to receive the support they needed to overcome the difficulties of the disease.

Although the children participating in this study were in different phases of the chronic illness, some receiving outpatient treatment, and others hospitalized, there was no difference in the perception of social support that they received, which means that no matter where they are, their care needs are natural and common, and they cannot be invisible to care actions.

Health professionals, especially nursing staff, need to raise awareness regarding this theme and focus on children with chronic disease, listening to their singularities, because they know what they need and at what time. Opening spaces for qualified listening, based on their perception of the healthdisease process, will allow these professionals to promote reflections in their daily work regarding strategies to provide comprehensive care and help them identify links in their social network which give them the support they need to successfully face 
the disease and also become effective components of that support network.

\section{REFERENCES}

1. Peterson-Carmichael SL, Cheifetz IM. The chronically critically ill patient: pediatric considerations. Respiratory Care. 2012 Jun; 57(6):993-1002.

2. Ingerski LM. A pilot study comparing traumatic stress symptoms by child and parent report across pediatric chronic illness groups. J Dev Behav Pediatr. 2010 NovDec; 31(9):713-19.

3. Ferro MA, Boyle MH. The impact of chronic physical illness, maternal depressive symptoms, family functioning, and self-esteem on symptoms of anxiety and depression in children. J Abnorm Child Psychol. 2015 Jan; 43(1):177-87.

4. Instituto Brasileiro de Geografia e Estatística (IBGE). Pesquisa Nacional por Amostra de Domicílios: um panorama da saúde no Brasil, acesso e utilização dos serviços, condições de saúde e fatores de risco e proteção à saúde. Rio de Janeiro (RJ): Fiocruz/MS/ IBGE; 2010.

5. Araújo YB, Collet N, Gomes IP, Nóbrega RD. Enfrentamento do adolescente em condição crônica: importância da rede social. Rev Bras Enferm. 2011 Mar-Abr; 64(2):281-6.

6. Pizzignacco TMP, Mello DF, Lima RAG. Estigma e fibrose cística. Rev Latino-Am Enfermagem. 2010 Jan-Fev; 18(1):139-42.

7. Gomes IP, Lima KA, Rodrigues LV, Lima RAG, Collet N. From diagnosis to survival of pediatric cancer: children's perspective. Texto Contexto Enferm [Internet]. 2013 Jul-Set [cited 2016 Apr 11]; 22(3):671-9. Available from: http://www. scielo.br/scielo.php?script=sci_arttext\&pid=S010407072013000300013\&lng=en\&nrm=iso\&tlng=en

8. Laakkonen H, Taskinen S, Rönnholm K, Holmberg C, Sandberg S. Parent-child and spousal relationships in families with a young child with end-stage renal disease. Pediatr Nephrol. 2014 Fev; 29(2):289-95.

9. Caixeta CRCB, Morrayne MA, Villela WV, Rocha SMM. Apoio social para pessoas vivendo com aids. Rev Enferm UFPE On Line [Internet]. 2011 Out [cited 2016 Apr 11]; 5(8):1920-30. Available from: http:// www.revista.ufpe.br/revistaenfermagem/index. php/revista/article/viewFile/1866/pdf_653

10. Di Primo AO, Schwartz E, Bielemann VLM, Burille A, Zillmer JGV, Feijó AM. Rede social e vínculos apoiadores das famílias de crianças com câncer. Texto Contexto Enferm. 2010 Abr-Jun; 19(2):334-2.

11. Coutinho MPL, Serafim RCNS, Araújo LS. A aplicabilidade de desenho-estória com tema no campo da pesquisa. In: Coutinho MPL, Saraiva ERA. Métodos de pesquisa em psicologia social: perspectivas qualitativas e quantitativas. João Pessoa (PB): Editora Universitária; 2011. p. 205-50.

12. Trinca W. Procedimento de desenhos-estórias: formas derivadas, desenvolvimentos e expansões. São Paulo (SP): Vetor Editora; 2013.

13. Minayo MCS. O desafio do conhecimento: pesquisa qualitativa em saúde. $14^{\text {a }}$ ed. São Paulo (SP): Hucitec; 2014.

14. Santos MA, Alves RCP, Oliveira VA, Ribas CRP, Teixeira, CRS, Zanetti, ML. Representações sociais de pessoas com diabetes acerca do apoio familiar percebido em relação ao tratamento. Rev Esc Enferm USP. 2011 Jun; 45(3):651-8.

15. Polita NB, Tacla MTGM. Rede e apoio social às famílias de crianças com paralisia cerebral. Esc Anna Nery. 2014 Jun; 18(1):75-81.

16. Pereira MM, Penha TP, Vaz EMC, Collet N, Reichert APS. Conceptions and practices of professional family health strategy for health education. Texto Contexto Enferm [Internet]. 2014 Mar [cited 2016 Apr 11]; 23(1):167-75. Available from: http:/ / www. scielo.br/scielo.php?script=sci_arttext\&pid=S010407072014000100167\&lng=en\&nrm=iso\&tlng=en

17. Golics CJ, Basra MKA, Salek MS, Finlay AY. The impact of patients chronic disease on family quality of life: an experience from 26 specialties. Int J Gen Med. 2013 Sep; 6:787-98.

18. Balistieri AS, Tavares CMM. A importância do apoio socioemocional em adolescentes e adultos jovens portadores de doença crônica: uma revisão de literatura. Enferm Global. 2013 Abr; 12(2):399-409.

19. Sparapani VC, Borges ALV, Dantas IRO, Pan R, Nascimento LC. A criança com diabetes mellitus tipo 1 e seus amigos: a influência dessa interação no manejo da doença. Rev Latino-Am Enfermagem. 2012 Jan-Fev; 20(1):117-25.

20. Brasil. Portaria Interministerial $n^{0} 1.010$, de 08 de maio de 2006: institui as diretrizes para a Promoção da Alimentação Saudável nas Escolas de educação infantil, fundamental e nível médio das redes públicas e privadas, em âmbito nacional. Diário Oficial da União,09 Mai 2006. 
21. Gomes-Villas Boas LC, Foss MC, Freitas MCF, Pace AE. Relationship among social support, treatment adherence and metabolic control of diabetes mellitus patients. Rev Latino-Am Enfermagem. 2012 Jan-Fev; 20(1):52-8.

22. Brasil. Resolução $n^{\circ} 41$, de 13 de outubro de 1995 : dispõe sobre os direitos da criança e do adolescente hospitalizados. Diário Oficial da União, 17 Out 1995.

23. Mello DB, Moreira MCN. A hospitalização e o adoecimento pela perspectiva de crianças e jovens portadores de fibrose cística e osteogênese imperfeita. Ciênc Saúde Coletiva. 2010 Mar; 15(2):453-61.

24. Lapa DF, Souza TV. A percepção do escolar sobre a hospitalização: contribuições para o cuidado de enfermagem. Rev Esc Enferm USP. 2011 Ago; 45(4):811-7.

25. Vasques RCY, Bousso RS, Mendes-Castillo AMC. A experiência de sofrimento: histórias narradas pela criança hospitalizada. Rev Esc Enferm USP. 2011 Mar; 45(1):122-9.

26. Dantas MAS, Collet N, Moura FM, Torquato IMB. Impacto do diagnóstico de paralisia cerebral para a família. Texto Contexto Enferm. 2010 Abr-Jun; 19(2):229-37.

27. Holanda ER, Collet N. As dificuldades da escolarização da criança com doença crônica no contexto hospitalar. Rev Esc Enferm USP. 2011 Abr; 45(2):381-9.

28. Nóbrega RD, Collet N, Gomes IP, Holanda ER, Araújo YB. Criança em idade escolar hospitalizada: significado da condição crônica. Texto Contexto Enferm. 2010 Jul-Set; 19(3):425-33.

29. Schneider KLK, Martini JG. Cotidiano do adolescente com doença crônica. Texto Contexto Enferm. 2011; 20(Esp):194-204. 